\title{
The Effect of Multiball Training Method Against Backhand Drive Stroke Accuracy in Table Tennis
}

\author{
A H Jumarsa ${ }^{1 *}$, Sukendro ${ }^{1}$, S Murniat ${ }^{1}$, Syafruddin ${ }^{1}$ \\ ${ }^{I}$ Faculty of Sport Science, Universitas Negeri Padang, Prof. Dr. Hamka, Padang, Indonesia \\ *Corresponding author. Email: arsahasendajumarsa31@yahoo.com
}

\begin{abstract}
This research was initiated by the low accuracy of the backhand drive table tennis of extracurricular participants. This research aims to determine the effect of multiball training method to the accuracy of table tennis backhand drive. The method used in this study was quantitative approach as the type of experimental research. The study design used was Randomizied pretest posttest Control Group Design. The population in this study was students who take extra-tennis table consisting of 20 people who were chosen as the sample since the sampling technique used was total sampling. The data analysis used was one way ANOVA $(\alpha=0.05)$. The research result shows that there is significant influence of multiball training methods to the accuracy of table tennis backhand drive of $22 \%$.
\end{abstract}

Keywords: Multiball training, backhand drive

\section{INTRODUCTION}

Basically the sport of table tennis is one sport that is popular in Indonesia in addition to other sports such as football and badminton. Recently, the game of table tennis is growing rapidly, both in the community, schools and in college, so competition is increasingly tight achievement. The level of achievement in sport of table tennis can be obtained with exercises done in a systematic, focused and sustained so that every player can play good quality produce. To achieve maximum performance is not easy to make it happen. Achievement in sports is strongly influenced by factors that is highly correlated with self-athletes include: physical ability, technique, tactics and psychological.

Achievement through the sport of table tennis is a tangible manifestation of qualified human Indonesia in its efforts to raise the dignity of the nation in the international world. The purpose of government in the field of sport contained in Article 20, paragraph 5, which states: to advance the sport achievements, the government, local governments and communities can develop: (a) The sports clubs, (b) the research and development of science and technology sport, (c) centers of sports coaching achievements, (d) education and training of personnel in sports, (e) infrastructure and facilities for sporting achievement, (f) the scouting system and the development of sporting talent, (G) sports information systems, and (h) to test the ability of an athlete achievement in the area of national and international level in accordance with needs. According Rihtiana and Tomoliyus (2014), The table tennis coaching will be better if it is supported by the equipment, sufficient training methods and program, supported funds, coach speciality, management and good organization.

Extracurricular activities are school programs in the form of student activities outside of formal lessons are generally beyond the standard curriculum study hours to develop their interests, talents, and skills of students. Extracurricular activities are scheduled and programmed routinely to adjust the academic calendar in order not to interfere with the learning process of its members.

Extracurricular at SMAN Titian Teras $H$. Abdurrahman Sayoeti Jambi has organized a coaching which is done through coaching and mentoring. Extracurricular at SMAN Titian Teras H. Abdurrahman Sayoeti Jambi grouped into areas of reasoning, in sports, the arts, and welfare or special. Table tennis extracurricular is one of the sport to train talented student in SMA Titian Teras H. Abdurrahman Sayoeti Jambi. During this time, table tennis extracurricular exercise was done once in a week.

Based on observations on that extracurricular, it was found that the students' backhand drive ability to pass the ball into the opposite fieldwas unsatisfactory. When the opponents forced to perform a quick rally, they often returns the ball too high, making it easier for the opponent take off the ball. Another mistake which is often made was to direct the ball to do a backhand drive. If the ball isnot well-directed, it will be detrimental to the player itself.

The game of table tennis needs a punch right towards the desired target as a factor of accuracy. Table tennis is very important in order to put the ball hard towards that hard to be returned by the opponent. There are several 
factors that cause low levels of accuracy backhand drive, which is hitting sixes impressed haste, the target blow improper, and of low precision. The importance of the level of accuracy in performing a backhand drive can affect the acquisition of a point in a game of table tennis. According to Suharno (2010), the determinants of whether or not the accuracy is high coordination, the size of the target, and a mastery of technique that is really going to have a good contribution to the accuracy of directing the movement, how quickly the movement,

Accuracy and backhand drive skill in a game of table tennis is an absolute necessity that should be owned by every player, because backhand drive is needed to carry out the attack, or defense to the opponent to shut down in order to get a point. Increasingly hard, flat, and directed a backhand drive that made it more likely to get a point. This technique needs to be mastered by students, and even become a mandatory technique to be possessed of a table tennis player. The precision backhand drive is closely related to the maturity and frequency of exercise. That is, to get the precision of a good backhand drive, the students have to practice intensively and terprogam. Any player who does a backhand drive has a different precision. This can be seen once at the time of a sparring partner as well as in the following game. Précised technique is a causative factor to deafeat or to win a match. Students still assume that backhand drive is not important and easy to do and does not pay attention to the accuracy of punches that do.

One way to improve performance in sports is the training methods appropriate to the objectives to be achieved. One goal is the formulation of varied exercises to motivate their students not to get bored practicing accuracy especially when doing exercises. According to Hodges (2007), the method of training in table tennis includes practicing with the other players, train with the coach, practicing alone, machinery and multiball. Of the various methods in table tennis, the researchers used training methods to improve the precision of the method backhand drive multiball practice. This training method emphasizes the frequency of beating, allowing students to get used to hit the ball to the target, so that the student movement into automation.

Based on the description that has been said above, the researchers conducted a study entitled "thw Effect of Multiball Training Method towards Against Backhand Drive Accuracy In Table Tennis Extracurricular Students of SMA Titian Teras H. Abdurrahman Sayoeti Jambi".

\section{METHOD}

The method in this study used quantitative approach to the type of experimental research. Experimental research is research conducted strictly to determine the causal relationship between the variables (Infallible: 2009). Based on the quantitative approach to the types of experiments above, the design or the design of the study is a "Randomizied Control group pretest posttest Design". This design is relatively close to perfect considering there was a control group with no treatment, subjects were placed randomly and their pretest posttest to ensure the effectiveness of the treatment given (Infallible: 2012).

The population in this study was students who took extracurricular table tennis, which amounted to 20 people. The research sample consisted of 20 people. The sampling technique is quota sampling. The research samples that were selected were then given the pretest of the accuracy of the table tennis backhand drive by using a table that had been given the target mark, and the results of the pretest were ranked. After ranking, samples are grouped into 2 groups with ordinal pairring techniques, namely: group I (experiment), and group II (control). After the sample is grouped, the sample is treated for 8 weeks (2 months) according to the training program that has been made. After being treated for 2 months, the sample was given posttest. The instrument that the researchers used in this study was the accuracy test instrument for table tennis backhand drive (Tomoliyus, 2012: 12), with a table that had been given the target mark size. There are 3 targets in this instrument, namely: a target with a size of $30 \times 30 \mathrm{~cm}$ (value 5), a target with a size of $60 \times 60 \mathrm{~cm}$ (value 3), and the remaining target with a value of 1 . The process of taking pretest and posttest is done for 30 seconds for one subject with 2 occasions. The first opportunity is 30 seconds and the second chance is also 30 seconds. The highest score of 2 times that opportunity will be used. In this study, the type of data to be collected is a skill test for the accuracy of the table tennis backhand drive. Subject data is presented in the form of scores obtained before treatment (pretest), and scores obtained after treatment (posttest). The data analysis technique in this study used one-way ANAVA with the help of SPSS (Statistical Pacage / Program for Social Science) version 16.0.

\section{RESULTS AND DISCUSSION}

The results of this study are that there is the influence of the multiball training method on the accuracy of the backhand drive hit on the table tennis extracurricular students of Titian Teras State High School $H$. Abdurrahman Sayoeti Jambi. The rule used to find out the presence or absence of significant influence is if a significant value is greater than 0.05 (significant $>0.05$ ) then $\mathrm{Ha}$ is rejected and if a significant value is less than 0.05 (significant $<0.05$ ) then $\mathrm{Ha}$ is accepted.

Based on the results of a simple linear regression test the control variable has a significant value of 0.118 and the experimental variable has a significant value of .000 . Because the sig of the control variable is greater than 0.05 , there is no significant effect while the significance variable experiment is less than 0.05 , so there is a significant effect.

The accuracy of the backhand drive is greatly influenced by several factors including the good and correct training methods. The accuracy of a good backhand drive is affected by the frequency and quality of good training. In terms of frequency of training, it can be concluded that with programmed training and a long time, the accuracy of students can continue to increase. This means that the more often students get training a 
precision, then the more mature in directing the target. In terms of the quality of training, the trainer must be able to create interesting and effective training methods. In table tennis there are 5 methods of training, namely training with other players, practicing with coaches, practicing on their own, machines, and multiball. In this study one of them is by providing multiball training methods. With this training method, students get more opportunities and often to hit the right backhand drive rather than using another method.

The multiball training method provides an opportunity for students to hit the ball that comes with direction, speed, and angle almost the same as what is done when the accuracy test of the backhand drive. This condition makes it easier for students to apply the theory of punching the accuracy of the backhand drive that has been obtained. This training method also provides a great opportunity for students to get used to hitting the ball with the accuracy of the intended backhand drive, so students can understand and apply the accuracy of the backhand drive in the real game. This increase is evident when the posttest data collection tests the accuracy of students' backhand drive blows in the experimental group, namely a significant increase in the experimental group students who received the balls training method compared to the control group students who did not receive the balls training method.

\section{CONCLUSION}

Based on the results of data analysis, description, testing the results of research and discussion, it can be concluded that there is an influence on the balls training method on the accuracy of the backhand drive hit on table tennis extracurricular students at Titian Teras State High School H. Abdurrahman Sayoeti Jambi. Can be seen from the average value of the experimental group, then obtained the average value of pretest 46.7 and the average value of posttest 57.1 , because the average value of the pretest is smaller than the average value of posttest, there is an increase in the accuracy of backhand drive punches of 10.4 with percentage increase of $22 \%$.

\section{REFERENCES}

[1] Hodges, L. (2007). Beginner Level Table Tennis. Jakarta: PT Raja Grafindo Persada.

[2] Maksum, A. (2012). Research Methodology in Sports. Surabaya: Unesa University Press.

[3] Rihtiana, V., \& Tomoliyus. (2014). Skills Assessment Instrument Development Engineering and backhand Forehand Drive in Table Tennis Athlete Early Childhood. Journal of Sport, 2 (2), 216-227.

[4] Suharno. (2010). Increased Physical Condition in Sports. Yogyakarta: UNY Press.

[5] Tomoliyus. (2012). Accuracy Instrument Development Capabilities Drive and backhand Forehand Drive in Table Tennis game. Yogyakarta: FIK UNY.

[6] Public Relations and Legal Bureau of the Ministry of Youth and the Sports Republic of Indonesia. (2010).
Law of the Republic of Indonesia No. 3 of 2005 on National Sports System. Jakarta: President. 